\title{
Uptake of dissolved free amino acids by four cold-water coral species from the Mediterranean Sea
}

\author{
Andrea Gori ${ }^{\mathrm{a}, *}$, Renaud Grover $^{\mathrm{a}}$, Covadonga Orejas ${ }^{\mathrm{b}}$, Séverine Sikorski ${ }^{\mathrm{a}}$, \\ Christine Ferrier-Pagès ${ }^{a}$ \\ ${ }^{a}$ Centre Scientifique de Monaco (CSM), Avenue Saint Martin, 98000, Monaco, Monaco \\ ${ }^{\mathrm{b}}$ Instituto Español de Oceanografía (IEO), Centro Oceanográfico de Baleares, Moll de Ponent s/n, 07015, Palma de Mallorca, Spain
}

\section{A R T I C L E I N F O}

\section{Available online 2 July 2013}

Keywords:

Cold-water corals

Dissolved free amino acids

Dissolved organic matter

Trophic ecology

Mediterranean Sea

\begin{abstract}
A B S T R A C T
Dissolved organic matter, which contains many compounds such as lipids, sugars and amino acids, is an important source of carbon and nitrogen for several symbiotic and asymbiotic tropical coral species. However, there is still no information on its possible uptake by cold-water coral species. In this study, we demonstrated that dissolved organic matter, in the form of dissolved free amino acids (DFAA), is actively absorbed by four cold-water coral species from the Mediterranean Sea. Although the uptake rates observed with $3 \mu \mathrm{M}$ DFAA concentration were one order of magnitude lower than those observed in tropical species, they corresponded to $12-50 \%$ of the daily excreted-nitrogen, and $16-89 \%$ of the daily respired-carbon of the cold-water corals. Consequently, DFAA, even at in situ concentrations lower than those tested in this study, can supply a significant amount of carbon and nitrogen to the corals, especially during periods when particulate food is scarce.
\end{abstract}

(c) 2013 Elsevier Ltd. All rights reserved.

\section{Introduction}

Distribution and abundance of cold-water coral (CWC) species are strongly influenced by several abiotic factors such as seawater temperature and density, aragonite saturation horizon, presence of appropriate substratum, and water flow regimes (Dullo et al., 2008; Orejas et al., 2009; Roberts et al., 2009a). Enhanced flows limit coral smothering by sediment, and play a crucial role in food supply (Roberts et al., 2009b), which has been considered as one of the main biotic factors explaining CWC distribution (Frederiksen et al., 1992; Mortensen et al., 2001; Kenyon et al., 2003; Thiem et al., 2006; Davies et al., 2009). Due to the major role of feeding in the ecology and physiology of coral species (Szmant-Froelich and Pilson, 1984; Naumann et al., 2011), several studies have investigated the diet of CWCs, and have demonstrated that they feed on a variety of food sources including phytodetritus, phytoplankton, and mesozooplankton (Duineveld et al., 2004, 2007, 2012; Kiriakoulakis et al., 2005; Carlier et al., 2009; Dodds et al., 2009), mainly herbivorous calanoid and omnivorous or carnivorous copepods (Henrich and Freiwald, 1997; Freiwald, 2002; Dodds et al., 2009; Roberts et al., 2009b). Laboratory experiments have also shown that CWCs can actively capture both dead and live particles (Mortensen, 2001; Roberts and Anderson, 2002), such as

\footnotetext{
* Corresponding author.

E-mail addresses: agori@centrescientifique.mc, agori.mail@gmail.com (A. Gori).
}

Artemia salina nauplii and adults (Purser et al., 2010; Tsounis et al. 2010). However, there is currently no information on their capacity to take up smaller particles, such as pico and nanoplankton, as well as dissolved organic matter.

Dissolved organic matter contains many biochemically identifiable classes of compounds, such as lipids, sugars and amino acids (Hansell and Carlson, 2001). Dissolved free amino acids (DFAA) have several origins, from phytoplankton exudates or consumption by zooplankton (Lee and Bada, 1977), to microbial decomposition of the sedimentary organic matter (Jørgensen, 1982; Bronk et al., 1994). Overall DFAA represent approximately $10 \%$ of the dissolved organic nitrogen in seawater (Sharp, 1983; Tada et al., 1998), and have been shown to be a potential food source for a wide range of marine invertebrates (e.g. Stephens and Schinske, 1961; Ferguson, 1982; Wright and Manahan, 1989; de Goeij et al., 2008a, 2008b). Although coral species are known to release dissolved organic matter into the seawater (Wild et al., 2008, 2010 and reference therein), some species are also known to actively take it up in the form of DFAA (Ferrier, 1991; Al-Moghrabi et al., 1993; Hoegh-Guldberg and Williamson, 1999; Grover et al., 2008). The fact that most animals have retained the capacity to take up dissolved organic matter indicates that it can be used as a source of nutrients and energy, especially when particulate food is scarce (Ferguson, 1982; Ambariyanto and Hoegh-Guldberg, 1999). The uptake of DFAA was indeed found to supply from $40 \%$ to $80 \%$ of the energetic requirements of some tropical coral species (Sorokin, 1981; Schlichter, 1982), while the 
entire metabolic rates could be sustained by DFAA in a temperate sea anemone (Schlichter, 1978).

Based on previous observations made on coral species, and given that no study has yet been performed on CWCs, we investigated the capacity of the four main CWC species from the Mediterranean Sea to actively take up dissolved organic matter in the form of DFAA. Subsequently, after quantifying the coral respiration and nitrogen excretion rates, we estimated the possible contribution of DFAA to the daily respired-carbon and excretednitrogen (Jørgensen, 1979; Szmant-Froelich and Pilson, 1984). The final aim of this work was to increase our knowledge on the trophic ecology of CWC species, and the role they can play in the marine food webs.

\section{Materials and methods}

\subsection{Coral collection and maintenance}

Specimens of Lophelia pertusa (Linnaeus, 1758), Madrepora oculata Linnaeus, 1758, Desmophyllum dianthus (Esper, 1794), and Dendrophyllia cornigera (Lamarck, 1816) were collected in the Cap de Creus Canyon (northwestern Mediterranean Sea, $42^{\circ} 23^{\prime} 20^{\prime \prime} \mathrm{N}$; $003^{\circ} 18^{\prime} 50^{\prime \prime} \mathrm{E}$ ). Highly energetic hydrodynamic and sedimentary processes, mainly linked to cold dense shelf water cascading events, continuously occur in the Cap de Creus Canyon (Canals et al., 2006, 2009) with down-canyon current velocities up to $80 \mathrm{~cm} \mathrm{~s}^{-1}$, maximum suspended sediment concentrations of $68 \mathrm{mg} \mathrm{L}^{-1}$, and maximum fluxes of $52 \mathrm{~g} \mathrm{~m}^{-2} \mathrm{~s}^{-1}$ (Palanques et al., 2006, 2012). Cap de Creus Canyon therefore acts as a preferential conduit of the dense shelf waters and associated suspended organic particles towards the slope region (Palanques et al., 2006, 2012) which sustain a high biological productivity inside the canyon (Orejas et al. 2009; Canals et al., 2009). Coral samples were collected from 200 to $400 \mathrm{~m}$ depth by means of the Remotely Operated Vehicle (ROV) PHANTOM HD2+2 and the manned submersible JAGO (IFM-GEOMAR, Kiel, Germany), and maintained alive on board the RV 'García del Cid' during the cruises 'Deep Coral I_Coral4' (July 2006) and 'HERMES IV_Coral8' (September 2007). Corals were then transported to the Centre Scientifique de Monaco (Monaco) and maintained in darkened $100 \mathrm{~L}$ tanks, with a continuous flow of Mediterranean seawater freshly pumped from $50 \mathrm{~m}$ depth at a rate of approximately $60 \mathrm{~L} \mathrm{~h}^{-1}$. Water temperature was maintained close to in situ conditions $\left(12 \pm 1.0^{\circ} \mathrm{C}\right)$ by chillers and $300 \mathrm{~W}$ heaters connected to independent temperature controllers. Two submersible pumps provided continuous water movement with a flow rate of $570 \mathrm{Lh}^{-1}$. Corals were fed twice a week with frozen Mysis (Crustacea, Eumalacostraca) and Cyclops (Crustacea, Copepoda). The polyp surface $(P S)$ of each coral specimen was determined by means of advanced geometry (Naumann et al., 2009) according to the equation $P S=\pi \cdot(r+R) \cdot a+\pi \cdot R^{2}$, where $r$ and $R$ represent respectively the basal and apical polyp radius, and $a$ is the apothem, measured with a caliper (Rodolfo-Metalpa et al., 2006).

\subsection{Calibration of DFAA measurements in the presence of ammonium}

The protocol used to measure DFAA uptake rates by the CWCs was adapted from the one previously used on tropical symbiotic corals by Grover et al. (2008) and Tremblay et al. (2012), after Parsons et al. (1984). This fluorometric method is precise, simple, with no needs for high-performance liquid chromatography (HPLC), and therefore very useful for routine analysis. A fluorescent reagent, $o$-phthalaldehyde, reacts with the primary amines of the DFAA in the presence of 2-mercaptoethanol, and the fluorescent products can be easily measured using a fluorometer. This technique works perfectly when there is no ammonium in seawater, because ammonium reacts positively with the fluorometric reagent $o$-phthalaldehyde, leading in this case to an overestimation of DFAA concentrations (Tada et al., 1998). Conversely to tropical corals which take up ammonium (Muscatine and D'Elia, 1978), CWCs excrete large amounts of ammonium during a few hours of incubation, and the DFAA measurement should therefore be corrected. For this purpose and for each incubation trial (see Section 2.3), a set of 20 standards was prepared using $50 \mu \mathrm{m}$ prefiltered seawater and a combination of DFAA (in the form of an algal mix, see Section 2.3) $(0,1.0,2.0$ and $3.0 \mu \mathrm{M})$ and ammonium $(0,1.0,3.45,7.28,9.62 \mu \mathrm{M})$ concentrations. Emission intensity of the fluorescence produced by the reaction with $o$-phthalaldehyde in each standard was quantified using a spectrofluorometer Xenius (Safas) following the protocol of Grover et al. (2008), after Parsons et al. (1984). Samples were excited at $342 \mathrm{~nm}$ wavelength, and emission intensity was measured at $452 \mathrm{~nm}$. Photomultiplier voltage was set up to $600 \mathrm{~V}$, and excitation and emission bandwidths to $10 \mathrm{~nm}$. The R-language function $\mathrm{Lm}$ of the $\mathrm{R}$ software platform (R Core Team, 2012) was used to perform multiple linear regressions between the emission intensities $(Y)$ measured for the 20 standards, and the DFAA $\left(x_{1}\right)$ and ammonium $(x 2)$ concentrations $\left(Y=\beta_{0}+\beta_{1} \cdot x_{1}+\beta_{2} \cdot x_{2}\right)$. Afterwards, the R-language function Summary was used to (1) test the adequacy of the obtained equations by means of an analysis of variance (ANOVA), (2) calculate the multiple regression coefficients of determination $\left(R^{2}\right)$, and (3) assess the significance of DFAA and ammonium concentrations in the explanation of the emission intensity. The equations of the regression plane obtained for each incubation trial were used to determine the DFAA concentration, corrected for the presence of ammonium measured in each sample of the subsequent incubations.

\subsection{Uptake of DFAA}

Uptake rates of DFAA by the four studied CWCs were assessed using an algal mix containing 19 different amino acids (Algal Amino Acid Mixture, ULM-2314-1, Lot PR-19236, Larodan Fine Chemicals $A B, 220$ Sweden), whose composition is close to the natural seawater DFAA composition (Tremblay et al., 2012). All control and experimental incubations with CWC specimen were performed in five replicates using beakers filled with $200 \mathrm{ml}$ seawater pre-filtered on $50 \mu \mathrm{m}$, maintained at a constant temperature of $12 \pm 0.5^{\circ} \mathrm{C}$ in a water bath, and enriched to a concentration of $3.0 \pm 0.1 \mu \mathrm{M}$ DFAA. Pre-filtration was performed on a $50 \mu \mathrm{m}$ filter to keep the microbial community in all control and experimental incubations. Water movement inside each beaker was obtained by means of a teflon-coated magnetic stirrer, and incubations ran for $6 \mathrm{~h}$. Seawater samples were taken from each beaker at the beginning and end of the incubations to quantify DFAA and ammonium concentration. Samples for DFAA analysis $(5 \mathrm{ml})$ were sterile filtered $(0.2 \mu \mathrm{m})$, and quantified as described above (see Section 2.2). Samples for ammonium analysis $(5 \mathrm{ml})$ were sterile filtered $(0.2 \mu \mathrm{m})$ and were kept frozen $\left(-20^{\circ} \mathrm{C}\right)$ until concentration of ammonium was determined by means of the spectrofluorometric method of Holmes et al. (1999) adapted by Godinot et al. (2011). DFAA concentrations were corrected for the presence of ammonium using the equations of the regression plane presented above (see Section 2.2). To assess if changes in DFAA concentration in the incubations with coral specimens can truly be explained by the uptake of the corals, three different control treatments were performed for each species. The first control consisted in five beakers only filled with pre-filtered seawater sampled in the CWCs' aquaria, to assess DFAA changes due to bacteria and other microorganisms present in seawater. 
The second control consisted in five beakers filled with pre-filtered seawater, and each containing a dead coral skeleton to assess the potential DFAA adsorption on dead material. The third control consisted in assessing DFAA changes due to bacteria present on coral mucus (Wild et al., 2008). For this purpose five beakers filled with pre-filtered seawater, and each containing a coral nubbin, were incubated without DFAA addition, during 6 h. Nubbins were then removed, leaving the released mucus and its associated bacteria in the beakers. DFAA were then added to the beakers, which were again incubated during $6 \mathrm{~h}$.

Mean variation in the DFAA measured from the control beakers was subtracted from those measured in the coral beakers, and DFAA uptake rates were derived from the variation over the $6 \mathrm{~h}$ incubation. All results, expressed as mean \pm standard deviation, were normalized to the coral surface area, in order to be comparable with previous results obtained with other scleractinian coral species. Moreover, DFAA uptake rates were also converted to carbon and nitrogen ( $\mu \mathrm{mol})$ equivalents by taking into account the composition of the DFAA mix and the total amount of carbon and nitrogen contained in each amino acid. Normal distribution of the data was tested using the Kolmogorov-Smirnov test performed with the R-language function ks.test, whereas homogeneity of variances was tested by means of the Bartlett test performed with the R-language function bartlett.test. Since variances were not homogeneous, the significance of DFAA depletion rates in coral compared to controls, as well as interspecific differences in DFAA uptake rates were tested with the non-parametric Kruskal-Wallis test performed with the R-language function kruskal.test. When significant differences were observed, a posteriori non-parametric multiple comparisons for relative contrast effects were performed with the R-language function nparcomp which is available in the nparcomp library.

\subsection{Coral respiration and excretion}

Coral respiration and excretion rates were assessed in incubations performed with five specimens from each studied species. Each specimen was incubated in a $370 \mathrm{ml}$ beaker, completely filled with $50 \mu \mathrm{m}$ pre-filtered seawater, closed with a plastic membrane, and maintained at a constant temperature of $12 \pm 0.5^{\circ} \mathrm{C}$ in a water bath. A control beaker without coral was run in parallel. Water movement inside each beaker was obtained by means of a tefloncoated magnetic stirrer, and incubations ran for $6 \mathrm{~h}$. Respiration rates were assessed by determining oxygen concentration from each beaker, at the beginning and end of the incubations, using a multiparametric sensor (Hach $\mathrm{HQ} 40 \mathrm{~b}$, precision $0.2 \mathrm{mg} \mathrm{L}^{-1}$ ). Variation in the oxygen concentration measured from the control beaker was subtracted from those measured in the coral beakers, and respiration rates were derived from the recorded depletion of dissolved oxygen over the incubation. Oxygen consumption rates were converted to carbon equivalents ( $\mu \mathrm{mol}$ ) according to the equation $C$ respired $=\mathrm{O}_{2}$ consumed . $R Q$, where $R Q$ is a coralspecific respiratory quotient equal to $0.8 \mathrm{~mol} \mathrm{C}: \mathrm{mol} \mathrm{O}_{2}$ (Muscatine et al., 1981; Anthony and Fabricius, 2000; Widdig and Schlichter, 2001; Ribes et al., 2003). Excretion rates were assessed by determining ammonium concentration in seawater samples $(5 \mathrm{ml})$ taken from each beaker at the beginning and end of the incubations. Samples were sterile filtered $(0.2 \mu \mathrm{m})$ and were kept frozen $\left(-20^{\circ} \mathrm{C}\right)$ until concentration of ammonium was determined by means of the spectrofluorometric method of Holmes et al. (1999). All results were normalized to the coral surface area, and are expressed as mean \pm standard deviation. After testing the normal distribution of the data and the homogeneity of variances with the R-language functions ks.test and bartlett.test, interspecific differences in respiration and excretion rates were tested by means of the non-parametric Kruskal-Wallis test performed with the function kruskal.test, since variances were not homogeneous. When significant differences were observed, a posteriori nonparametric multiple comparisons for relative contrast effects were performed with the function nparcomp.

\section{Results}

\subsection{Calibration of DFAA measurements in the presence of ammonium}

Multiple linear regressions adequately represented the relationship between the relative fluorescence intensity measured, and the DFAA and ammonium concentrations (ANOVA, $p<0.001$ ). Both DFAA (t test, $p<0.001$ ) and ammonium (t test, $p<0.001$ ) concentrations resulted to be significant in the explanation of the emission intensity. The regression plans obtained (Fig. 1 and Table 1) presented high regression coefficients of determination $\left(R^{2}>0.997\right)$. Thus, the equation obtained for each incubation were confidently used to calculate the DFAA concentration, while correcting for the effect of the measured ammonium concentration.

\subsection{Uptake of DFAA}

Significant depletion of DFAA by coral nubbins compared to the controls was observed in L. pertusa (Kruskal-Wallis test, $p=0.007$ ), D. cornigera (Kruskal-Wallis test, $p=0.004$ ), M. oculata (KruskalWallis test, $p=0.006$ ), and $D$. dianthus (Kruskal-Wallis test, $p=0.013$ ) (Table 2), whereas no significant differences were observed among the control treatments for all the species (Table 3). Normalized to the coral surface area, DFAA uptake rates were equivalent to $0.083 \pm 0.022 \mu \mathrm{mol} \mathrm{cm}{ }^{-2} \mathrm{~d}^{-1}$ for $L$. pertusa, $0.066 \pm 0.010 \mu \mathrm{mol} \mathrm{cm}^{-2} \mathrm{~d}^{-1}$ for $M$. oculata, $0.075 \pm 0.022$ $\mu \mathrm{mol} \mathrm{cm}{ }^{-2} \mathrm{~d}^{-1}$ for $D$. dianthus, and $0.050 \pm 0.010 \mu \mathrm{mol} \mathrm{cm}{ }^{-2} \mathrm{~d}^{-1}$ for $D$. cornigera (Fig. 2), without significant differences among the four species (Kruskal-Wallis test, $p=0.063$ ). In terms of total carbon and nitrogen ingested (Table 2), these rates corresponded to $0.242-0.400 \mu \mathrm{mol} \mathrm{C} \mathrm{cm}{ }^{-2} \mathrm{~d}^{-1}$ and $0.060-0.100$ $\mu \mathrm{mol} \mathrm{N} \mathrm{cm} \mathrm{C}^{-2} \mathrm{~d}^{-1}$, respectively.

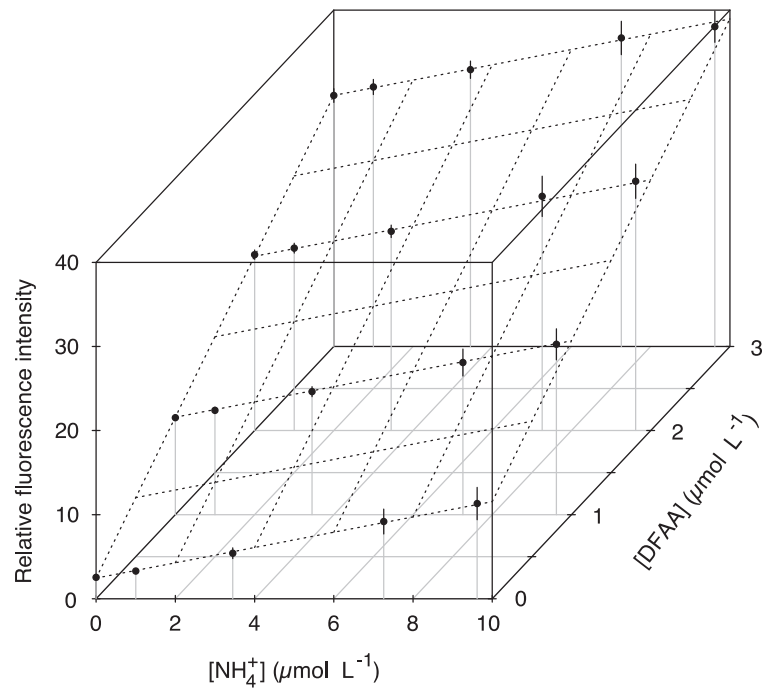

Fig. 1. Emission intensity of the fluorescence (mean \pm SD) measured in the 20 standards prepared for each incubation using $50 \mu \mathrm{m}$ pre-filtered seawater and combination of DFAA and ammonium concentrations. Regression plan obtained by multiple linear regressions, represents the relationship between the relative fluorescence intensity measured, and the DFAA and ammonium concentrations. 
Table 1

Relative fluorescence intensity (RFI) produced by the reaction (see Section 2.2) in the standards prepared using a combination of DFAA and ammonium concentrations.

\begin{tabular}{|c|c|c|c|}
\hline \multirow[t]{2}{*}{ DFAA $(\mu \mathrm{M})$} & \multirow[t]{2}{*}{ Ammonium $(\mu \mathrm{M})$} & \multicolumn{2}{|l|}{ RFI } \\
\hline & & Mean & $\mathrm{SD}$ \\
\hline \multirow[t]{5}{*}{0} & 0 & 2.54 & 0.31 \\
\hline & 1 & 3.30 & 0.27 \\
\hline & 3.45 & 5.41 & 0.64 \\
\hline & 7.28 & 9.18 & 1.48 \\
\hline & 9.62 & 11.32 & 1.92 \\
\hline \multirow[t]{5}{*}{1} & 0 & 11.53 & 0.29 \\
\hline & 1 & 12.41 & 0.38 \\
\hline & 3.45 & 14.63 & 0.60 \\
\hline & 7.28 & 18.09 & 1.60 \\
\hline & 9.62 & 20.26 & 1.85 \\
\hline \multirow[t]{5}{*}{2} & 0 & 20.92 & 0.56 \\
\hline & 1 & 21.70 & 0.59 \\
\hline & 3.45 & 23.70 & 0.74 \\
\hline & 7.28 & 27.86 & 2.40 \\
\hline & 9.62 & 29.65 & 2.04 \\
\hline \multirow[t]{5}{*}{3} & 0 & 29.85 & 0.82 \\
\hline & 1 & 30.86 & 0.90 \\
\hline & 3.45 & 32.92 & 1.03 \\
\hline & 7.28 & 36.69 & 1.98 \\
\hline & 9.62 & 38.03 & 1.85 \\
\hline
\end{tabular}

\subsection{Coral respiration and excretion}

Oxygen depletion observed in the incubation chambers $(0.4-$ $6.0 \mu \mathrm{mol} \mathrm{L}{ }^{-1} \mathrm{~h}^{-1}$ ) was clearly distinguishable from oxygen depletion in control chambers attributable to microbial respiration $\left(<0.3 \mu \mathrm{mol} \mathrm{L}^{-1} \mathrm{~h}^{-1}\right)$. Normalized to the coral surface area, respiration rates were equivalent to $0.47 \pm 0.15 \mu \mathrm{mol} \mathrm{C} \mathrm{cm}{ }^{-2} \mathrm{~d}^{-1}$ for $L$. pertusa, $0.64 \pm 0.14 \mu \mathrm{mol} \mathrm{C} \mathrm{cm}{ }^{-2} \mathrm{~d}^{-1}$ for M. oculata, $1.34 \pm$ $0.31 \mu \mathrm{mol} \mathrm{C} \mathrm{cm}{ }^{-2} \mathrm{~d}^{-1}$ for $D$. dianthus, and $1.57 \pm 0.32 \mu \mathrm{mol} \mathrm{C}$ $\mathrm{cm}^{-2} \mathrm{~d}^{-1}$ for $D$. cornigera (Fig. 3a), with significant differences among the four species (Kruskal-Wallis test, $p=0.002$ ), with L. pertusa and M. oculata respiring significantly less than $D$. dianthus and $D$. cornigera $(p<0.001)$. The observed uptake of DFAA covered the following amount of daily respired-carbon: $88.6 \pm 21.2 \%$ for $L$. pertusa, $51.1 \pm 6.8 \%$ for $M$. oculata, $27.4 \pm 5.9 \%$ for $D$. dianthus, and $15.6 \pm 2.5 \%$ for $D$. cornigera.

Changes in ammonium concentration observed in the incubation chambers $\left(0.27-1.76 \mu \mathrm{mol} \mathrm{L}^{-1} \mathrm{~h}^{-1}\right)$ were clearly distinguishable from the changes observed in control chambers $(<0.15$ $\left.\mu \mathrm{mol} \mathrm{L} \mathrm{L}^{-1} \mathrm{~h}^{-1}\right)$. Normalized to the coral surface area, ammonium excretion rates were equivalent to $0.37 \pm 0.07 \mu \mathrm{mol} \mathrm{N} \mathrm{cm}^{-2}$ $\mathrm{d}^{-1}$ for L. pertusa, $0.16 \pm 0.02 \mu \mathrm{mol} \mathrm{N} \mathrm{cm}{ }^{-2} \mathrm{~d}^{-1}$ for $M$. oculata, $0.40 \pm 0.15 \mu \mathrm{mol} \mathrm{N} \mathrm{cm}^{-2} \overline{\mathrm{d}}^{-1}$ for $D$. dianthus, and $0.52 \pm 0.20$ $\mu \mathrm{mol} \mathrm{N} \mathrm{cm}{ }^{-2} \mathrm{~d}^{-1}$ for $D$. cornigera (Fig. 3b), with significant differences among the four species (Kruskal-Wallis test, $p=0.011$ ), with $M$. oculata excreting significantly less than the other species $(p<0.001)$. The observed uptake of DFAA covered the following amount of daily excreted-nitrogen: $26.7 \pm 3.9 \%$ for $L$. pertusa, $49.6 \pm 5.1 \%$ for M. oculata, $24.0 \pm 6.8 \%$ for D. dianthus, and $12.1 \pm$ $3.2 \%$ for $D$. cornigera.

\section{Discussion}

This study assesses, for the first time, the capacity of four CWC species to take up dissolved organic matter in the form of DFAA from the surrounding waters. The effectiveness of corals for taking up DFAA depends on DFAA concentration and composition in seawater (Grover et al., 2008), which are both currently unknown in CWC environments. The concentration tested in this study $\left(3.0 \mu \mathrm{mol} \mathrm{L}^{-1}\right)$ is high compared to the values usually measured in open ocean (0.1-1.0 $\mu \mathrm{mol} \mathrm{L}^{-1}$, Lee and Bada, 1977; Henrichs and Williams, 1985; Keil and Kirchman, 1999) and tropical coral reefs waters (0.05-1.0 $\mu \mathrm{mol} \mathrm{L}^{-1}$, Ferrier, 1991; Hoegh-Guldberg, 1994; Ben-David-Zaslow and Benayahu, 2000 and references herein). However, CWCs are reported to be associated with areas of high surface primary productivity (Guinotte et al., 2006; Davies et al., 2008), which are also correlated with high DFAA concentrations (Poulet et al., 1985). During downwelling events, these surface waters can be rapidly advected to the bottom where CWC dwell (Roberts et al., 2009a), likely providing pulses of high concentrations of particulate and dissolved organic matter. In the Mediterranean Sea, downwellings occur simultaneously with spring phytoplankton blooms, advecting fresh organic matter to the submarine canyons of the Gulf of Lions and the Adriatic Sea (Palanques et al., 2006; Fabres et al., 2008; Canals et al., 2009), where dense CWC populations have been observed (Taviani et al., 2005; Orejas et al., 2009; Vertino et al., 2010; Gori et al., 2013). Interplays between topography and tides also lead to rapid downwellings of fresh organic matter to the CWC reefs in the Sea of the Hebrides (northeast Atlantic) (Davies et al., 2009; Roberts et al., 2009b; Duineveld et al., 2012). Moreover, near bottom waters (Ferguson, 1982) and interstitial sediment waters (North, 1975; Henrichs and Farrington, 1979; Jørgensen and Kristensen, 1980) contain significantly more DFAA $\left(4-13 \mu \mathrm{mol} \mathrm{L}^{-1}\right)$ than that higher in the water column. This may increase the possibility for CWCs to be exposed to somewhat elevated DFAA concentrations, at least when sediment is removed by bioturbation or strong currents. Finally, DFAA concentrations may be increased adjacent to corals over very small spatial and temporal scales, for example during prey capture, when nematocyst discharges are believed to cause leakage of body fluids (including DFAA) from zooplankters (Ferrier, 1991).

Although DFAA concentrations surrounding CWCs remain to be precisely estimated, uptake rates of $3 \mu \mathrm{M}$ DFAA, measured in this study, can be compared to those estimated with other coral species performed with the same DFAA concentration. Uptake rates by CWCs (from 0.050 to $0.083 \mu \mathrm{mol}$ DFAA cm ${ }^{-2} \mathrm{~d}^{-1}$ ) are thus one order of magnitude lower than those observed in tropical corals (from 0.10 to $0.82 \mu \mathrm{mol}$ DFAA $\mathrm{cm}^{-2} \mathrm{~d}^{-1}$; Ferrier, 1991; Hoegh-Guldberg and Williamson, 1999; Grover et al., 2008; Tremblay et al., 2012). This discrepancy might be explained by a different thermal environment, which affects the affinity of the DFAA carrier systems. Indeed, the transport of amino acids in corals is an active process, mediated by either Na-dependent or Na-independent carrier systems (Al-Moghrabi et al., 1993). Their kinetic parameters, such as the affinity constant, were shown to be dependent on both seawater temperature and coral trophic status (Al-Moghrabi et al., 1993; Shotwell et al., 1983). Temperature effect has also been clearly demonstrated with bacteria, with a negative correlation between temperature and the response time to DFAA enrichment (Shiah and Ducklow, 1994).

Concerning nitrogen excretion, rates measured for the CWC species (from 0.16 to $0.52 \mu \mathrm{mol} \mathrm{N} \mathrm{cm}{ }^{-2} \mathrm{~d}^{-1}$ ) were similar to values observed in asymbiotic tropical corals $\left(\sim 0.50 \mu \mathrm{mol} \mathrm{N} \mathrm{cm}^{-2} \mathrm{~d}^{-1}\right.$, Szmant et al., 1990), but lower than those observed in temperate species (1.17-2.65 $\mu \mathrm{mol} \mathrm{N} \mathrm{cm}{ }^{-2} \mathrm{~d}^{-1}$, Szmant-Froelich and Pilson, 1984). In deep waters, nitrogen excretion by corals is an obligatory step in resupplying pools of dissolved inorganic nitrogen (DIN) that sustain a high microbial activity in the vicinity of the corals (Wild et al., 2008). An intense coral-microbial interaction via coral mucus production has indeed already been highlighted (Wild et al., 2008), and the release of ammonium, directly usable by bacteria is thus an additional tool to maintain this dynamic microbial loop. There were notable differences in nitrogen excretion between the CWC 
Table 2

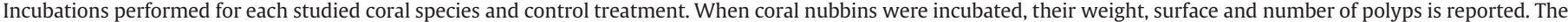

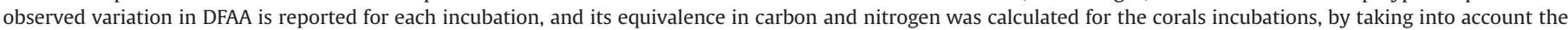
composition of the DFAA mix and the total amount of carbon and nitrogen contained in each amino acid.

\begin{tabular}{|c|c|c|c|c|c|c|c|c|}
\hline \multirow[t]{2}{*}{ Species } & \multirow[t]{2}{*}{ Treatment } & \multirow[t]{2}{*}{ Replicates } & \multirow[t]{2}{*}{ Weight (g) } & \multirow[t]{2}{*}{ Surface $\left(\mathrm{cm}^{2}\right)$} & \multirow[t]{2}{*}{ Number of polyps } & \multirow[t]{2}{*}{$\Delta$ DFAA $(\mu \mathrm{mol})$} & \multicolumn{2}{|c|}{ Equivalent ingestion } \\
\hline & & & & & & & $\mathrm{C}(\mu \mathrm{mol})$ & $\mathrm{N}(\mu \mathrm{mol})$ \\
\hline \multirow[t]{20}{*}{ Lophelia pertusa } & Corals & 1 & 3.92 & 20.5 & 7 & 0.310 & 1.504 & 0.374 \\
\hline & & 2 & 2.23 & 11.8 & 8 & 0.281 & 1.364 & 0.340 \\
\hline & & 3 & 7.64 & 21.8 & 7 & 0.368 & 1.783 & 0.444 \\
\hline & & 4 & 1.29 & 7.8 & 3 & 0.197 & 0.957 & 0.238 \\
\hline & & 5 & 1.67 & 7.6 & 4 & 0.234 & 1.135 & 0.283 \\
\hline & Skeletons & 1 & 1.56 & 7.4 & 5 & 0.014 & & \\
\hline & & 2 & 1.48 & 5.6 & 6 & 0.020 & & \\
\hline & & 3 & 2.36 & 7.9 & 8 & 0.006 & & \\
\hline & & 4 & 5.91 & 13.9 & 8 & 0.013 & & \\
\hline & & 5 & 3.05 & 12.5 & 6 & 0.034 & & \\
\hline & Mucus & 1 & 3.92 & 20.5 & 7 & 0.025 & & \\
\hline & & 2 & 2.23 & 11.8 & 8 & 0.102 & & \\
\hline & & 3 & 7.64 & 21.8 & 7 & 0.027 & & \\
\hline & & 4 & 1.29 & 7.8 & 3 & 0.014 & & \\
\hline & & 5 & 1.67 & 7.6 & 4 & 0.033 & & \\
\hline & Seawater & 1 & & & & 0.030 & & \\
\hline & & 2 & & & & 0.013 & & \\
\hline & & 3 & & & & 0.012 & & \\
\hline & & 4 & & & & 0.011 & & \\
\hline & & 5 & & & & 0.034 & & \\
\hline Madrepora oculata & Corals & 1 & 1.64 & 7.3 & 18 & 0.142 & 0.690 & 0.172 \\
\hline & & 2 & 1.96 & 8.6 & 25 & 0.174 & 0.844 & 0.210 \\
\hline & & 3 & 2.46 & 13.3 & 24 & 0.181 & 0.877 & 0.218 \\
\hline & & 4 & 2.64 & 12.2 & 16 & 0.217 & 1.052 & 0.262 \\
\hline & & 5 & 1.87 & 9.9 & 27 & 0.161 & 0.779 & 0.194 \\
\hline & Skeletons & 1 & 0.85 & 6.1 & 11 & 0.021 & & \\
\hline & & 2 & 0.81 & 8.0 & 12 & 0.035 & & \\
\hline & & 3 & 1.52 & 6.4 & 12 & 0.010 & & \\
\hline & & 4 & 1.09 & 6.8 & 9 & 0.027 & & \\
\hline & & 5 & 1.19 & 6.7 & 11 & 0.001 & & \\
\hline & Mucus & 1 & 1.64 & 7.3 & 18 & 0.011 & & \\
\hline & & 2 & 1.96 & 8.6 & 25 & 0.005 & & \\
\hline & & 3 & 2.46 & 13.3 & 24 & 0.002 & & \\
\hline & & 4 & 2.64 & 12.2 & 16 & 0.004 & & \\
\hline & & 5 & 1.87 & 9.9 & 27 & 0.003 & & \\
\hline & Seawater & 1 & & & & 0.020 & & \\
\hline & & 2 & & & & 0.007 & & \\
\hline & & 3 & & & & 0.008 & & \\
\hline & & 4 & & & & 0.003 & & \\
\hline & & 5 & & & & 0.013 & & \\
\hline Desmophyllum dianthus & Corals & 1 & 5.57 & 15.7 & 1 & 0.389 & 1.888 & 0.470 \\
\hline & & 2 & 7.07 & 21.3 & 1 & 0.260 & 1.260 & 0.314 \\
\hline & & 3 & 4.42 & 12.9 & 1 & 0.313 & 1.518 & 0.378 \\
\hline & & 4 & 3.86 & 12.8 & 1 & 0.287 & 1.392 & 0.346 \\
\hline & & 5 & 7.30 & 18.3 & 1 & 0.285 & 1.381 & 0.344 \\
\hline & Skeletons & 1 & 2.14 & 11.0 & 1 & 0.027 & & \\
\hline & & 2 & 1.38 & 7.2 & 1 & 0.001 & & \\
\hline & & 3 & 2.64 & 17.1 & 1 & 0.025 & & \\
\hline & & 4 & 1.12 & 9.3 & 1 & 0.018 & & \\
\hline & & 5 & 1.45 & 10.1 & 1 & 0.005 & & \\
\hline & Mucus & 1 & 5.57 & 15.7 & 1 & 0.010 & & \\
\hline & & 2 & 7.07 & 21.3 & 1 & 0.011 & & \\
\hline & & 3 & 4.42 & 12.9 & 1 & 0.021 & & \\
\hline & & 4 & 3.86 & 12.8 & 1 & 0.031 & & \\
\hline & & 5 & 7.30 & 18.3 & 1 & 0.012 & & \\
\hline & Seawater & 1 & & & & 0.028 & & \\
\hline & & 2 & & & & 0.006 & & \\
\hline & & 3 & & & & 0.011 & & \\
\hline & & 4 & & & & 0.018 & & \\
\hline & & 5 & & & & 0.015 & & \\
\hline Dendrophyllia cornigera & Corals & 1 & 8.78 & 21.3 & 2 & 0.248 & 1.201 & 0.299 \\
\hline & & 2 & 4.93 & 13.7 & 1 & 0.134 & 0.648 & 0.161 \\
\hline & & 3 & 4.65 & 12.6 & 3 & 0.128 & 0.619 & 0.154 \\
\hline & & 4 & 2.06 & 8.2 & 1 & 0.111 & 0.536 & 0.133 \\
\hline & & 5 & 10.43 & 18.4 & 1 & 0.291 & 1.414 & 0.352 \\
\hline & Skeletons & 1 & 2.11 & 9.9 & 1 & 0.043 & & \\
\hline & & 2 & 6.39 & 14.9 & 2 & 0.105 & & \\
\hline & & 3 & 0.66 & 4.7 & 1 & 0.006 & & \\
\hline & & 4 & 2.00 & 9.3 & 1 & $0 ; 001$ & & \\
\hline
\end{tabular}


Table 2 (continued)

\begin{tabular}{|c|c|c|c|c|c|c|c|c|}
\hline \multirow[t]{2}{*}{ Species } & \multirow[t]{2}{*}{ Treatment } & \multirow[t]{2}{*}{ Replicates } & \multirow[t]{2}{*}{ Weight (g) } & \multirow[t]{2}{*}{ Surface $\left(\mathrm{cm}^{2}\right)$} & \multirow[t]{2}{*}{ Number of polyps } & \multirow[t]{2}{*}{$\Delta$ DFAA $(\mu \mathrm{mol})$} & \multicolumn{2}{|c|}{ Equivalent ingestion } \\
\hline & & & & & & & $\mathrm{C}(\mu \mathrm{mol})$ & $\mathrm{N}(\mu \mathrm{mol})$ \\
\hline & & 5 & 0.87 & 3.4 & 1 & 0.003 & & \\
\hline & Mucus & 1 & 8.78 & 21.3 & 2 & 0.008 & & \\
\hline & & 2 & 4.93 & 13.7 & 1 & 0.010 & & \\
\hline & & 3 & 4.65 & 12.6 & 3 & 0.014 & & \\
\hline & & 4 & 2.06 & 8.2 & 1 & 0.018 & & \\
\hline & & 5 & 10.43 & 18.4 & 1 & 0.018 & & \\
\hline & Seawater & 1 & & & & 0.013 & & \\
\hline & & 2 & & & & 0.004 & & \\
\hline & & 3 & & & & 0.001 & & \\
\hline & & 4 & & & & 0.004 & & \\
\hline & & 5 & & & & 0.001 & & \\
\hline
\end{tabular}

Table 3

Nonparametric multiple comparison procedure of the DFAA variation in the incubations with coral nubbins and the control treatments (see Section 2.3); significant $\mathrm{p}$-values are indicated with one ( $p$-value $<0.05)$, two ( $p$-value $<0.01$ ), or three asterisks ( $p$-value $<0.001$ ).

\begin{tabular}{|c|c|c|c|c|}
\hline Species & Treatments & $t$ & $p$-value & \\
\hline \multirow[t]{6}{*}{ Lophelia pertusa } & Corals/skeleton & -9.76 & $<0.001$ & $* * *$ \\
\hline & Corals/mucus & -9.76 & $<0.001$ & $* * *$ \\
\hline & Corals/seawater & -9.76 & $<0.001$ & $* * *$ \\
\hline & Skeleton/mucus & 1.28 & 0.706 & \\
\hline & Skeleton/seawater & 0.09 & 0.999 & \\
\hline & Mucus/seawater & 0.99 & 0.879 & \\
\hline \multirow[t]{6}{*}{ Madrepora oculata } & Corals/skeleton & -9.76 & $<0.001$ & $* * *$ \\
\hline & Corals/mucus & -9.76 & $<0.001$ & *** \\
\hline & Corals/seawater & -9.76 & $<0.001$ & $* * *$ \\
\hline & Skeleton/mucus & -1.06 & 0.831 & \\
\hline & Skeleton/seawater & 0.94 & 0.891 & \\
\hline & Mucus/seawater & -1.33 & 0.658 & \\
\hline \multirow[t]{6}{*}{ Desmophyllum dianthus } & Corals/skeleton & -9.76 & $<0.001$ & $* * *$ \\
\hline & Corals/mucus & -9.76 & $<0.001$ & $* * *$ \\
\hline & Corals/seawater & -9.76 & $<0.001$ & *** \\
\hline & Skeleton/mucus & 0.273 & 0.999 & \\
\hline & Skeleton/seawater & -0.18 & 0.999 & \\
\hline & Mucus/seawater & 0.192 & 0.999 & \\
\hline \multirow[t]{6}{*}{ Dendrophyllia cornigera } & Corals/skeleton & -9.76 & $<0.001$ & $* * *$ \\
\hline & Corals/mucus & -9.76 & $<0.001$ & $* * *$ \\
\hline & Corals/seawater & -9.76 & $<0.001$ & *** \\
\hline & Skeleton/mucus & 0.40 & 0.999 & \\
\hline & Skeleton/seawater & 0.87 & 0.934 & \\
\hline & Mucus/seawater & 1.92 & 0.275 & \\
\hline
\end{tabular}

species, with the lowest excretion rate for $M$. oculata $\left(0.2 \mu \mathrm{mol} \mathrm{N} \mathrm{cm}{ }^{-2} \mathrm{day}^{-1}\right)$ and the highest rate for $D$. dianthus $\left(0.6 \mu \mathrm{mol} \mathrm{N} \mathrm{cm}{ }^{-2}\right.$ day $\left.^{-1}\right)$, reflecting differences in species metabolism since ammonium is mostly formed by the catabolism of proteins (Wright, 1995). Indeed, respiration rates of $D$. dianthus measured in this study and in a previous one at a similar temperature (Naumann et al., 2011) were at least three times higher than in M. oculata. Therefore, depending on the species metabolism, $3 \mu \mathrm{M}$ DFAA can account for $12-50 \%$ of the daily excreted-nitrogen. This contribution is in the range of previous estimations made on tropical corals for an equivalent DFAA concentration (20\% of nitrogen requirements of S. pistillata, Grover et al., 2008 and from 8.5 to $14.7 \%$ of P. damicornis, Hoegh-Guldberg and Williamson, 1999). Concerning respiration rates, DFAA uptake can cover between 16 and $89 \%$ of the daily respired-carbon, depending on the species. This contribution was higher in the branched species (L. pertusa and M. oculata) than in the massive ones ( $D$. cornigera and $D$. dianthus) due to the much higher respiration rates of the massive species, possibly related to their larger amount of tissue. Overall, DFAA contribution to the daily

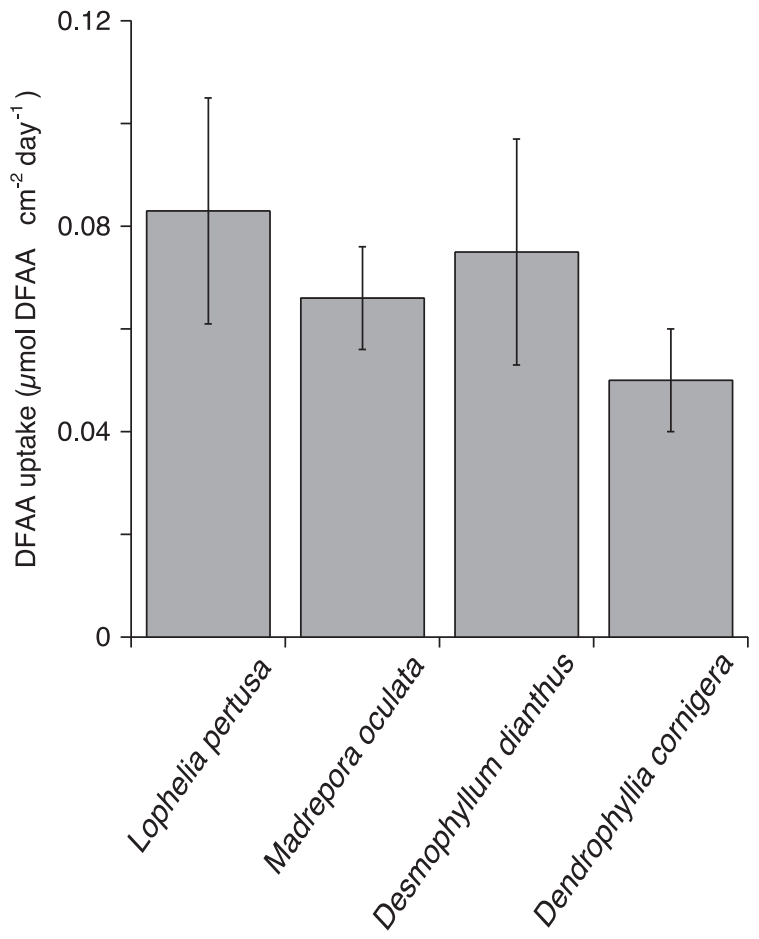

Fig. 2. Dissolved free amino acid (DFAA) uptake rates (mean \pm SD) for the four studied species (at initial concentration of $3.0 \pm 0.1 \mu \mathrm{M}$ DFAA), expressed as $\mu \mathrm{mol}$ DFAA $\mathrm{cm}^{-2}$ of coral surface $\mathrm{d}^{-1}$.

respired-carbon in the CWCs is higher than estimations of $10 \%$ made for tropical corals (Grover et al., 2008; Tremblay et al., 2012), for a comparable DFAA concentration in seawater. However, it has to be noticed that respiration rates in this study (ranging between 0.47 and $1.57 \mu \mathrm{mol} \mathrm{C} \mathrm{cm}^{-2} \mathrm{~d}^{-1}$ ) were much lower than those

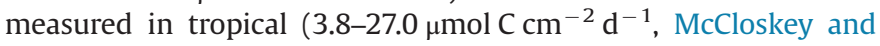
Muscatine, 1984; Szmant et al., 1990; Houlbrèque et al., 2003) and temperate coral species (3.3-16 $\mu \mathrm{mol} \mathrm{C} \mathrm{cm}{ }^{-2} \mathrm{~d}^{-1}$, Szmant-Froelich and Pilson, 1984; Rodolfo-Metalpa et al., 2008; Tremblay et al., 2011), and even in L. pertusa from northeast Atlantic (7.2 $\mu \mathrm{mol} \mathrm{O}_{2}$ $\mathrm{cm}^{-2} \mathrm{~d}^{-1}$ at $11^{\circ} \mathrm{C}$, Dodds et al., 2007). Overall, respiration rates for $D$. dianthus in this study $\left(1.34 \pm 0.31 \mu \mathrm{mol} \mathrm{C} \mathrm{cm}{ }^{-2} \mathrm{~d}^{-1}\right)$ were in the same order of magnitude than those reported for starved corals of the same species $\left(\sim 1.5 \mu \mathrm{mol} \mathrm{C} \mathrm{cm}^{-2} \mathrm{~d}^{-1}\right.$, Naumann et al., 2011), evidencing that corals in our experiment showed a reduced metabolic activity, possibly as a consequence of the low feeding frequency (twice a week). Consequently, during periods when particulate food is scarce, the observed uptake of DFAA could potentially cover a larger amount of carbon and nitrogen metabolic 
(A)

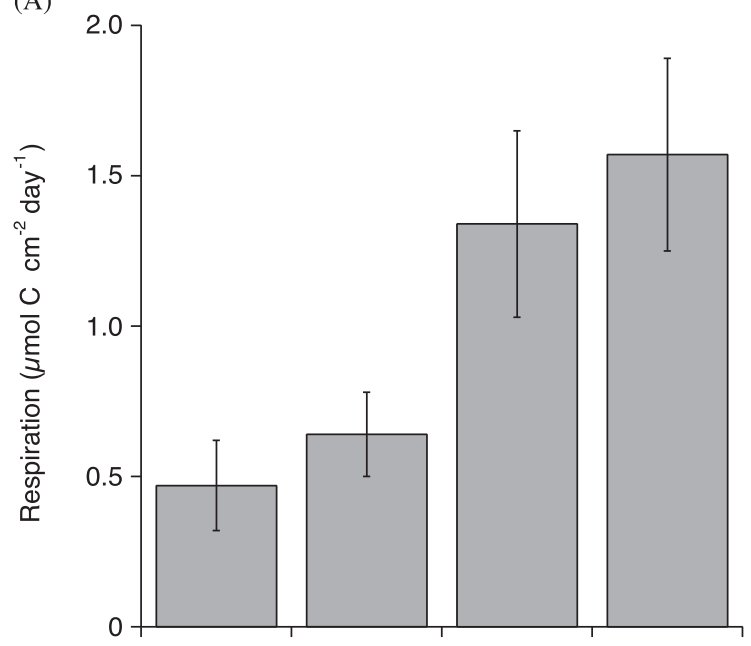

(B)

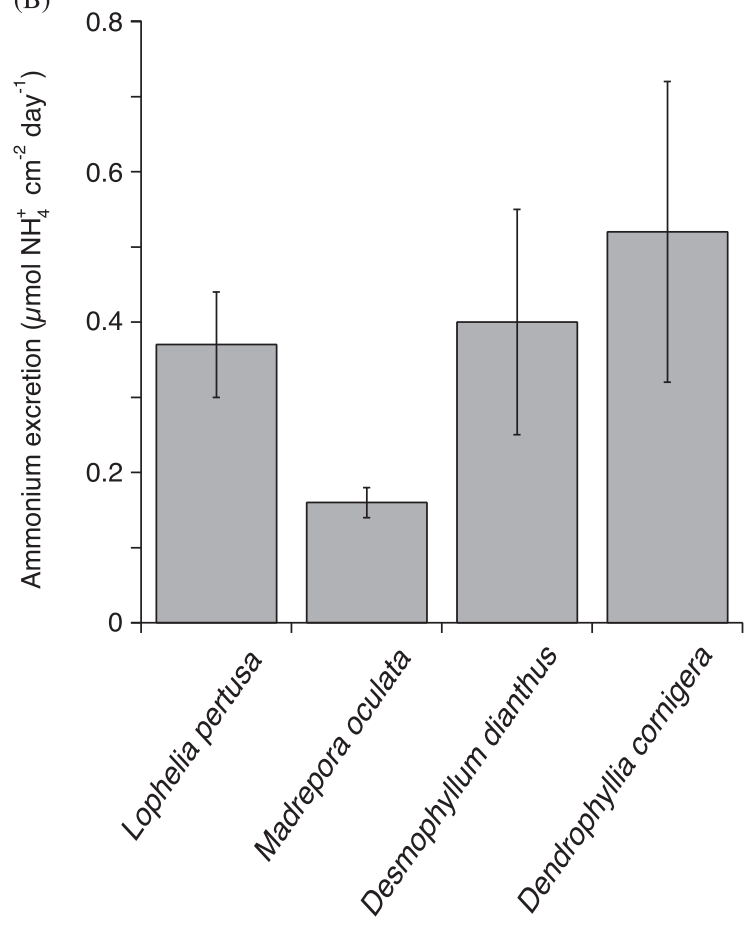

Fig. 3. Rates of (a) respiration and (b) ammonium excretion (mean \pm SD) for the four studied species, expressed as $\mu \mathrm{mol} \mathrm{C}$ and $\mathrm{N} \mathrm{cm}^{-2}$ of coral surface $\mathrm{d}^{-1}$.

requirements in the studied CWC species than in tropical or temperate species.

\section{Conclusions}

In conclusion, the data presented in this study have demonstrated uptake of DFAA by CWCs. For a comparable concentration of DFAA in seawater, CWC species presented much lower uptake rates compared to tropical corals, suggesting a possible role of temperature in the uptake of DFAA by scleractinian corals, or a different affinity in the DFAA carrier systems. Even so, due to the lower metabolism of CWCs, the contribution of $3 \mu \mathrm{M}$ DFAA to daily respired-carbon and excreted-nitrogen was higher in CWCs than in tropical corals. DFAA concentration tested in this study is likely to be higher than those experienced by CWCs in the field. However, since potential CWC prey items are patchily distributed and in addition may be diluted, uptake of DOM may supplement the diet of CWCs when particulate food is scarce (Szmant et al., 1990; Naumann et al., 2011).

\section{Acknowledgments}

The authors are indebted to J.M. Gili and to the crew and scientists on board the RV 'García del Cid', as well as to the JAGOteam, J. Schauer and K. Hissmann (IFM-GEOMAR, Kiel, Germany) for supporting the coral collection. We are grateful to C. Rottier and S. Reynaud, as well as to the personnel from the Musée Océanographique de Monaco for helping with the coral care, to D. Allemand for discussions. This work was supported by the Government of the Principality of Monaco, and by the European Project HERMIONE (Grant Agreement Number 226354).

\section{References}

Al-Moghrabi, S., Allemand, D., Jaubert, J., 1993. Valine uptake by the scleractinian coral Galaxea fascicularis: characterization and effect of light and nutrient status. J. Comp. Physiol. B 193, 355-362.

Ambariyanto, Hoegh-Guldberg, O., 1999. Net uptake of dissolved free amino acids by the giant clam, Tridacna maxima: alternative sources of energy and nitrogen? Coral Reefs 18, 91-96.

Anthony, K.R.N., Fabricius, K.E., 2000. Shifting roles of heterotrophy and autotrophy in coral energy budgets at variable turbidity. J. Exp. Mar. Biol. Ecol. 252, 221-253.

Ben-David-Zaslow, R., Benayahu, Y., 2000. Biochemical composition, metabolism, and amino acid transport in planula-larvae of the soft coral Heteroxenic fuscescens. J. Exp. Zool. 287, 401-412.

Bronk, D.A., Gilbert, P.M., Ward, B.B., 1994. Nitrogen uptake, dissolved organic nitrogen release, and new production. Science 265, 1843-1846.

Canals, M., Puig, P., Durrieu de Madron, X., Heussner, S., Palanques, A., Fabrés, J. 2006. Flushing submarine canyons. Nature 444, 354-357.

Canals, M., Danovaro, R., Heussner, S., Lykousis, V., Puig, P., Trincardi, F., Calafat, A. M., Durrieu de Madron, X., Palanques, A., Sànchez-Vidal, A., 2009. Cascades in Meiterranean submarine grand canyons. Oceanograpy 22, 26-43.

Carlier, A., Le Guilloux, E., Olu, K., Sarrazin, J., Mastrototaro, F., Taviani, M., Clavier, J., 2009. Trophic relationships in a deep Mediterranean cold-water coral bank (Santa Maria di Leuca, Ionian Sea). Mar. Ecol. Prog. Ser. 397, 125-137.

Davies, A.J., Wisshak, M., Orr, J.C., Roberts, J.M., 2008. Predicting suitable habitat for the cold-water coral Lophelia pertusa (Scleractinia). Deep-Sea Res. I 55 1048-1062.

Davies, A.J., Duineveld, G.C.A., Lavaleye, M.S.S., Bergman, M.J.N., van Haren, H., Roberts, J.M., 2009. Downwelling and deep-water bottom currents as food supply mechanisms to the cold-water coral Lophelia pertusa (Scleractinia) at the Mingulay Reef complex. Limnol. Oceanogr. 54, 620-629.

De Goeij, J.M., van den Berg, H., van Oostveen, M.M., Epping, E.H.G., van Duyl, F.C., 2008a. Major bulk DOM removal by encrusting coral reef cavity sponges. Mar Ecol. Prog. Ser. 357, 139-151.

De Goeij, J.M., Moodley, L., Houtekamer, M., Carballeira, N.M., van Duyl, F.C., 2008b. Tracing ${ }^{13} \mathrm{C}$-enriched dissolved and particulate organic carbon in the bacteria containing coral reef sponge Halisarca caerulea: evidence for DOM-feeding. Limnol. Oceanogr. 53, 1376-1386.

Dodds, L.A., Black, K.D., Orr, H., Roberts, J.M., 2009. Lipid biomarkers reveal geographical differences in food supply to the cold-water coral Lophelia pertusa (Scleractinia). Mar. Ecol. Prog. Ser. 397, 113-124.

Dodds, L.A., Roberts, J.M., Taylor, A.C., Marubini, F., 2007. Metabolic tolerance of the cold-water coral Lophelia pertusa (Scleractinia) to temperature and dissolved oxygen change. Journal of Experimental Marine Biology and Ecology 349, 205-214.

Duineveld, G.C.A., Lavaleye, M.S.S., Berghuis, E.M., 2004. Particle flux and food supply to a seamount cold-water coral community (Galicia Bank, NW Spain). Mar. Ecol. Prog. Ser. 277, 13-23.

Duineveld, G.C.A., Lavaleye, M.S.S., Bergman, M.J.N., de Stigter, H., Mienis, F., 2007. Trophic structure of a cold-water coral mound community (Rockall Bank, NE Atlantic) in relation to the near-bottom particle supply and current regime. Bull. Mar. Sci. 81, 449-467.

Duineveld, G.C.A., Jeffreys, R.M., Lavaleye, M.S.S., Davies, A.J., Bergman, M.J.N., Watmough, T., Witbaard, R., 2012. Spatial and tidal variation in food supply to shallow cold-water coral reefs of the Mingulay Reef complex (Outer Hebrides, Scotland). Mar. Ecol. Prog. Ser. 444, 97-115.

Dullo, W.C., Flögel, S., Rüggeberg, A., 2008. Cold-water coral growth in relation to the hydrography of the Celtic and Nordic European continental margin. Mar Ecol. Prog. Ser. 371, 165-176.

Fabres, J., Tesi, T., Velez, J., Batista, F., Lee, C., Calafat, A., Heussner, S., Palanques, A. Miserocchi, S., 2008. Seasonal and event-controlled export of organic matter from the shelf towards the Gulf of Lions continental slope. Cont. Shelf Res. 28, 1971-1983. 
Ferguson, J.C., 1982. A comparative study of the net metabolic benefits derived from the uptake and release of free amino acids by marine invertebrates. Biol. Bull. 162, 1-17.

Ferrier, M.D., 1991. Net uptake of dissolved free amino acids by four scleractinian corals. Coral Reefs 10, 183-187.

Frederiksen, R., Jensen, A., Westerberg, H., 1992. The distribution of the scleractinian coral Lophelia pertusa around the Faroe Islands and the relation to internal tidal mixing. Sarsia 77, 157-171.

Freiwald, A., 2002. Reef-forming cold-water corals. In: Wefer, G., Billett, D. Hebbeln, D., Jørgensen, B.B., Schlüter, M., van Weering, T. (Eds.), Ocean Margin Systems. Springer, Berlin, pp. 365-385.

Godinot, C., Grover, R., Allemand, D., Ferrier-Pagès, C., 2011. High phosphate uptake requirements of the scleractinian coral Stylophora pistillata. J. Exp. Biol. 214 2749-2754.

Gori, A., Orejas, C., Madurell, T., Bramanti, L., Martins, M., Quintanilla, E., Marti-Puig, P. Lo Iacono, C., Puig, P., Requena, S., Greenacre, M., Gili, J.M., 2013. Bathymetrical distribution and size structure of cold-water coral populations in the Cap de Creus and Lacaze-Duthiers canyons (northwestern Mediterranean). Biogeosciences 10, 2049-2060.

Grover, R., Maguer, J.F., Allemand, D., Ferrier-Pagès, C., 2008. Uptake of dissolved free amino acids by the scleractinian coral Stylophora pistillata. J. Exp. Biol. 211, 860-865.

Guinotte, J.M., Orr, J., Cairns, S., Freiwald, A., Morgan, L., George, R., 2006. Will human-induced changes in seawater chemistry alter the distribution of deepsea scleractinian corals? Front. Ecol. Environ. 4, 141-146.

Hansell, D.A., Carlson, C.A., 2001. Marine dissolved organic matter and the carbon cycle. Oceanography 14, 41-49.

Henrich, R., Freiwald, A., Shipboard Party, 1997. Lophelia reef on Sula Ridge, midNorwegian shelf. Cruise Report No. 228/97, IFM-GEOMAR, Kiel.

Henrichs, S.M., Farrington, J.W., 1979. Amino acids in interstitial waters of marine sediments. Nature 297, 955-959.

Henrichs, S.M., Williams, P.M., 1985. Dissolved and particulate amino acids and carbohydrates in the sea surface microlayer. Mar. Chem. 17, 141-163.

Hoegh-Guldberg, O., 1994. Uptake of dissolved organic matter by larval stage of the crown-of-thorns starfish Acanthaster planci. Mar. Biol. 120, 55-63.

Hoegh-Guldberg, O., Williamson, J., 1999. Availability of two forms of dissolved nitrogen to the coral Pocillopora damicornis and its symbiotic zooxanthellae. Mar. Biol. 133, 561-570.

Holmes, R.M., Aminot, A., Kérouel, R., Hooker, B.A., Peterson, B.J., 1999. A simple and precise method for measuring ammonium in marine and freshwater ecosystems. Can. J. Fish. Aquat. Sci. 56, 1801-1808.

Houlbrèque, F., Tambutté, E., Ferrier-Pagés, C., 2003. Effect of zooplankton availability on the rates of photosynthesis, and tissue and skeletal growth in the scleractinian coral Stylophora pistillata. J. Exp. Mar. Biol. Ecol. 296, 145-166.

Jørgensen, N.O.G., 1979. Uptake of L-valine and other amino acids by the polychaete Nereis virens. Mar. Biol. 52, 45-52.

Jørgensen, N.O.G., 1982. Heterotrophic assimilation and occurrence of dissolved free amino acids in a shallow estuary. Mar. Ecol. Prog. Ser. 8, 145-159.

Jørgensen, N.O.G., Kristensen, E., 1980. Uptake of amino acids by three species of Nereis (Anellida: Polycaeta). I. Transport kinetics and net uptake from natural concentrations. Mar. Ecol. Prog. Ser. 3, 329-340.

Keil, R.G., Kirchman, D.L., 1999. Utilization of dissolved protein and amino acids in the northern Sargasso Sea. Aquat. Micob. Ecol. 18, 293-300.

Kenyon, N.H., Akhmetzhanov, A.M., Wheeler, A.J., van Weering, T.C.E., de Hass, H., Ivanov, M.K., 2003. Giant carbonate mud mounds in the southern Rockall Trough. Mar. Geol. 195, 5-30.

Kiriakoulakis, K., Fischer, E., Wolff, G.A., Freiwald, A., Grehan, A., Roberts, J.M., 2005 Lipids and nitrogen isotopes of two deep-water corals from the North-East Atlantic: initial results and implications fro their nutrition. In: Freiwald, A., Roberts, J.M. (Eds.), Cold-Water Corals and Ecosystems. Springer, Berlin, pp. 715-729.

Lee, C., Bada, J.L., 1977. Dissolved amino acids in the equatorial Pacific, the Sargasso Sea, and Biscayne Bay. Limnol. Oceanogr. 22, 502-510.

McCloskey, L.R., Muscatine, L., 1984. Production and respiration in the Red Sea cora Stylophora pistillata as a function of depth. Proc. R. Soc. Lond. B 222, 215-230.

Mortensen, P.B., 2001. Aquarium observations on the deep-water coral Lophelic pertusa (L., 1758) (Scleractinia) and selected associated invertebrates. Ophelia 54, 83-104.

Mortensen, P.B., Hovland, M.T., Fosså, J.H., Furevik, D.M., 2001. Distribution, abundance and size of Lophelia pertusa coral reefs in mid-Norway in relation to seabed characteristics. J. Mar. Biol. Assoc. UK 81, 581-597.

Muscatine, L., D'Elia, C.F., 1978. The uptake, retention, and release of ammonium by reef corals. Limnol. Oceanogr. 23, 725-734.

Muscatine, L., McCloskey, L.R., Marian, R.E., 1981. Estimating the daily contribution of carbon from zooxanthellae to animal respiration. Limnol. Oceanogr. 26, 601-611.

Naumann, M.S., Niggl, W., Laforsch, C., Glaser, C., Wild, C., 2009. Coral surface area quantification-evaluation of established techniques by comparison with computer tomography. Coral Reefs 28, 109-117.

Naumann, M.S., Orejas, C., Wild, C., Ferrier-Pagès, C., 2011. First evidence for zooplankton feeding sustaining key physiological processes in a scleractinian cold-water coral. J. Exp. Biol. 214, 3570-3576.

North, B.B., 1975. Primary amines in California coastal waters: utilization by phytoplankton. Limnol. Oceanogr. 20, 20-27.

Orejas, C., Gori, A., Lo Iacono, C., Puig, P., Gili, J.M., Dale, M.R.T., 2009. Cold-water corals in the Cap de Creus canyon, northwestern Mediterranean: spatia distribution, density and anthropogenic impact. Mar. Ecol. Prog. Ser. 397, 37-51.
Palanques, A., Durrieu de Madron, X., Puig, P., Fabres, J., Guillén, J., Calafat, A., Canals, M., Heussner, S., Bonnin, J., 2006. Suspended sediment fluxes and transport processes in the Gulf of Lions submarine canyons. The role of storms and dense water cascading. Mar. Geol. 234, 43-61.

Palanques, A., Puig, P., Durrieu de Madron, X., Sanchez-Vidal, A., Pasqual, C., Martín, J., Calafat, A., Heusner, S., Canals, M., 2012. Sediment transport to the deep canyons and open-slope of the western Gulf of Lions during the 2006 intense cascading and open-sea convection period. Prog. Oceanogr. 106, 1-15.

Parsons, T.M., Maita, Y., Lalli, C.M., 1984. Determination of dissolved free amino acids by fluorometric analysis. In: Parsons, T.M., Maita, Y., Lalli, C.M. (Eds.), A Manual of Chemical and Biological Methods for Seawater Analysis. Pergammon Press, Oxford, pp. 40-44.

Poulet, S.A., Martin-Jezequel, V., Delmas, D., 1985. Gradient of dissolved free amino acids and phytoplankton in a shallow bay. Hydrobiologia 121, 11-17.

Purser, A., Larsson, A.I., Thomsen, L., van Oevelen, D., 2010. The influence of flow velocity and food concentration on Lophelia pertusa (Scleractinia) zooplankton capture rates. J. Exp. Mar. Biol. Ecol. 395, 55-62.

$\mathrm{R}$ Core Team, 2012. R: A language and environment for statistical computing. $\mathrm{R}$ Foundation for Statistical Computing, Vienna, Austria. ISBN 3-900051- 07-0, URL. 〈http://www.R-project.org $\rangle$.

Ribes, M., Coma, R., Rossi, S., 2003. Natural feeding of the temperate asymbiotic octocoral-gorgonian Leptogorgia sarmentosa (Cnidaria: Octocorallia). Mar. Ecol. Prog. Ser. 254, 141-150.

Roberts, J.M., Anderson, R.M., 2002. A new laboratory method for monitoring deepwater coral polyp. Hydrobiologia 471, 143-148.

Roberts, J.M., Wheeler, A.J., Freiwald, A., Cairns, S., 2009a. Cold-water Corals: The Biology and Geology of Deep-sea Coral Habitats. Cambridge University Press, Cambridge.

Roberts, J.M., Davies, A.J., Henry, L.A., Dodds, L.A., Duineveld, G.C.A., Lavaleye, M.S.S., Maier, C., van Soest, R.W.M., Bergman, M.J.N., Hühnerbach, V., Huvenne, V.A.I., Sinclair, D.J., Watmough, T., Long, D., Green, S.L., van Haren, H., 2009b. Mingulay reef complex: an interdisciplinary study of cold-water coral habitat, hydrography and biodiversity. Mar. Ecol. Prog. Ser. 397, 139-151.

Rodolfo-Metalpa, R., Richard, C., Allemand, D., Bianchi, C.N., Morri, C., Ferrier-Pagès, C., 2006. Response of zooxanthellae in symbiosis with the Mediterranean corals Cladocora caespitosa and Oculina patagonica to elevated temperatures. Mar. Biol. 150, 45-55.

Rodolfo-Metalpa, R., Huot, Y., Ferrier-Pagès, C., 2008. Photosynthetic response of the Mediterranean zooxanthellate coral Cladocora caespitosa to the natural range of light and temperature. J. Exp. Biol. 211, 1579-1586.

Schlichter, D., 1978. On the ability of Anemonia sulcata (Coelenterata: Anthozoa) to absorb charged and neutral amino acids simultaneously. Mar. Biol. 45, 97-104.

Schlichter, D., 1982. Epidermal nutrition of the Alcyonarian Heteroxenia fuscescens (Ehrb.): absorption of dissolved organic material and lost endogenous photosynthates. Oecologia 53, 40-49.

Sharp, J.H., 1983. The distributions of inorganic nitrogen and dissolved and particulate organic nitrogen in the sea. In: Carpenter, E.J., Capone, D.G. (Eds.), Nitrogen in the Marine Environment. Academic Press, New York, pp. 1-35.

Shiah, F.K., Ducklow, H.W., 1994. Temperature regulation of heterotrophic bacterioplankton abundance, production, and specific growth rate in Chesapeake Bay. Limnol. Oceanogr. 39, 1243-1258.

Shotwell, M.A., Kilber, M.S., Oxender, D.L., 1983. The regulation of neutral amino acid transport in mammalian cells. Biochim. Biophys. Acta 737, 267-284.

Sorokin, Y.I., 1981. Aspects of the biomass, feeding and metabolism of common corals of the Great Barrier Reef, Australia. Proceedings of the Fourth International Coral Reef Symposium 2, 27-32.

Stephens, G.C., Schinske, R.A., 1961. Uptake of amino acids by marine invertebrates. Limnol. Oceanogr. 6, 175-181.

Szmant, A.M., Ferrer, L.M., FitzGerald, L.M., 1990. Nitrogen excretion and O:N ratios in reef corals: evidence for conservation of nitrogen. Mar. Biol. 104, 119-127.

Szmant-Froelich, A., Pilson, M.E.Q., 1984. Effects of feeding frequency and symbiosis with zooxanthellae on nitrogen metabolism and respiration of the coral Astrangia danae. Mar. Biol. 81, 153-162.

Tada, K., Tada, M., Maita, Y., 1998. Dissolved free amino acids in coastal seawater using a modified fluorometric method. J. Oceanogr. 54, 313-321.

Taviani, M., Remia, A., Corselli, C., Freiwald, A., Malinverno, E., Mastrototaro, F., Savini, A., Tursi, A., 2005. First geo-marine survey of living cold-water Lophelia reefs in the Ionian Sea (Mediterranean basin). Facies 50, 409-417.

Thiem, Ø., Ravagnan, E., Fossă, J.H., Berntsen, J., 2006. Food supply mechanisms for cold-water corals along a continental shelf edge. J. Mar. Syst. 26, 1481-1495.

Tremblay, P., Peirano, A., Ferrier-Pagès, C., 2011. Heterotrophy in the Mediterranean symbiotic coral Cladocora caespitosa: comparison with two other scleractinian species. Mar. Ecol. Prog. Ser. 422, 165-177.

Tremblay, P., Naumann, M.S., Sikorski, S., Grover, R., Ferrier-Pagès, C., 2012. Experimental assessment of organic carbon fluxes in the scleractinian coral Stylophora pistillata during a thermal and photo stress event. Mar. Ecol. Prog. Ser. 453, 63-77.

Tsounis, G., Orejas, C., Reynaud, S., Gili, J.M., Allemand, D., Ferrier-Pagès, C., 2010. Prey-capture rates in four Mediterranean cold water corals. Mar. Ecol. Prog. Ser. 398, 149-155.

Vertino, A., Savini, A., Rosso, A., Di Geronimo, I., Mastrototaro, F., Sanfilippo, R., Gay, G., Etiope, G., 2010. Benthic habitat characterization and distribution from two representative sites of the deep-water SML Coral Province (Mediterranean). Deep-Sea Res. II 57, 380-396.

Widdig, A., Schlichter, D., 2001. Phytoplankton: a significant trophic source for soft corals? Helgol. Mar. Res. 55, 198-211. 
Wild, C., Mayr, C., Wehrmann, L., Schöttner, S., Naumann, M., Hoffmann, F., Rapp, H. T., 2008. Organic matter release by cold water corals and its implication for fauna-microbe interaction. Mar. Ecol. Prog. Ser. 372, 67-75.

Wild, C., Niggl, W., Naumann, M.S., Haas, A.F., 2010. Organic matter release by Red Sea coral reef organisms-potential effects on microbial activity and in situ $\mathrm{O} 2$ availability. Mar. Ecol. Prog. Ser. 411, 61-71.
Wright, P., 1995. Nitrogen excretion: three end products, many physiological roles. J. Exp. Biol. 198, 273-281.

Wright, S.H., Manahan, D.T., 1989. Integumental nutrient uptake by aquatic organisms. Ann. Rev. Physiol. 51, 585-600. 